\title{
Rainwater harvesting experiences of the CIDECALLI and CFE
}

\author{
M. Anaya-Garduño ${ }^{1}$, G. Arvizu-Lara ${ }^{2}$, J. D. Martínez-Nájera², \\ V. Arévalo-Mendoza ${ }^{2}$, B. E. Martínez-Castillo ${ }^{1}$, \\ M. I. Martínez-Ponce ${ }^{1} \&$ J. Chacón-Rodríguez ${ }^{1}$ \\ ${ }^{1}$ Centro Internacional de Demostración y Capacitación en \\ Aprovechamiento del Agua de Lluvia del Colegio de Postgraduados, \\ Mexico \\ ${ }^{2}$ Comisión Federal de Electricidad, Mexico
}

\begin{abstract}
Rainwater harvesting dates from ancient times, beginning in the Middle East more than 4000 years ago, in countries and regions such as Jordan, Mesopotamia and Palestine; these were progressively developed in Asia and America. Recently, rainwater harvesting is again an outstanding option for mitigation of water scarcity worldwide. Water in rivers, lakes, surface reservoirs and aquifers is increasingly impaired, which identifies that rainwater is a meaningful option for the supply. Its extensive use contributes to sustainable water management, reducing supply problems. Rainwater can be used in the whole range of human activities. Its benefits are environmental and economic. This paper shows the experiences of the International Centre for Demonstration and Training on Rainwater Harvesting (CIDECALLI, for its acronym in Spanish) of the Graduate College of Chapingo and Federal Electricity Commission (CFE), México, in the development of prototypes for the use of rainwater for human consumption at the level of family and community, backyard production, controlled environments, animal consumption, workplaces, aquifer recharge, and industry which have been developed in México and several countries in Latin America.

Keywords: rainwater harvesting systems, sustainable water management.
\end{abstract}




\section{Introduction}

Of the 7000 million people in the world, 1400 million are without access to piped water; in 2025 could be about 3000 million people without access to safe drinking water. There are millions of isolated communities with less than 200 inhabitants, which are and will be unlikely to have the vital liquid. $85 \%$ of Third World diseases are caused by poor water quality, each year 443 million lost school days due to water-related diseases, millions of women spend up to four hours a day to fetch water (Anaya-Garduño [1, 2]). Currently the collection, storage and treatment of rainwater harvesting systems (RWHS) represents a real option and cost to meet demand for human consumption in domestic use, production in controlled environments and backyards, rainfed agriculture, and industry. México is the first country that purifies and packages rainwater in marginalized rural communities, and is planning to apply fluoride and folic acid, e.g. $[3,4]$.

Evidence shows that RWHS has been used since memorial times for agriculture, livestock, and human purposes. Technologies on rainwater catchment systems have been developed empirically rather than scientifically. RWHS dates from ancient times, beginning in the Middle East for more than 4000 years, in countries and regions such as Jordan, Mesopotamia and Palestine. RWHS were progressively developed in Asia: Pakistan, Yemen, India, China, Sri Lanka; Africa: Tunisia, Somalia, Sudan, Burkina Faso; North America: United States (Arizona, New México and Texas), as well as México (in Aztec and Mayan cultures); and Latin America and the Caribbean countries: Brazil, Argentina, Nicaragua, Honduras, Guatemala, Costa Rica, Virgin Islands and the Dominican Republic. Recently, rainwater harvesting is again an outstanding option for mitigation of water scarcity worldwide.

México currently farms 22 million ha of its land, $70 \%$ under rain-fed conditions. This is a potential dangerous situation since, giving the projected population of 125 million by the year 2025 and an upper limit of farmable land of about 24 million ha, the country will have an average of only 0.23 ha per capita at its disposal. If adequate measures are not taken, misery, migration and famine will surely result (Anaya-Garduño $[1,2]$ ).

The paper presents experiences of the International Centre for Demonstration and Training on Rainwater Harvesting (CIDECALLI, for its Spanish acronym) of the Graduate College and Federal-Electricity Commission (CFE), both of México, in the development of prototypes for the use of rainwater for human consumption at the level of family and community, backyard production, controlled environments, animal consumption, aquifer recharge, and industry which have been developed in México and several countries in Latin America and the Caribbean (Guatemala, Salvador, Honduras, Nicaragua, Costa Rica, Panamá and Dominican Republic). It has also established the International Network of Specialized people on Rainwater Harvesting Systems (RIECALLI). Besides, it has been established agreements of collaboration at national and international levels. RWHS merit consideration as a component of a large-scale water resource development; it is a need to establish national and municipal 
programs for the diffusion of alternative technologies. México has already dynamic growing demands of water for human consumption, and mainly for basic crops and forage production, and industrial requirements.

\section{Contemporary types of RWHS}

\subsection{Terracing}

Terracing is a simple application of rain catchment but on a large-scale. Low walls are built along the contours of the slope to form stones and rock fragments. Their uphill sides are filled with soil collected from the slope between terraces UNEP [5]. The water was either stored in the soil of the cultivated area, or sometimes artificial storage facilities are constructed, such as open, lined tanks or closed cisterns. A growing number of studies focusing in detail on contemporary terraces include Patrick's work in Tlaxcala [6]; West's work in the Valley of México and Hidalgo [7]; Johnson's work in the Mezquital Valley [8]; Sanders' and Carlton's [9], work on the Teotihuacan Valley; and Wilken's [10], review of traditional forms of slope management.

The main aim of these structures is to interrupt and retain slope runoff and alluvium. Over time, alluvium builds up behind the barriers thereby increasing infiltration and enchanting the soil moisture storage capacity of the fields. One of the most important aspects of contour terracing in México is that it requires very low investments in capital and relatively low investments in labor. Wilken [10], observing a government-sponsored contour terrace project in Tlaxcala, México, describes the process as follows:

On the gently to moderately sloping agricultural lands, ejidatarios cut trapezoidal drainage ditches (zanjas), $60 \mathrm{~cm}$ deep and $80 \mathrm{~cm}$ wide at the top sloping to $40 \mathrm{~cm}$ at the bottom. Zanja lines are laid out along contours then precisely cut with shoves, spades and picks. Dividing strips 50 to $60 \mathrm{~cm}$ wide, but only 30 to $40 \mathrm{~cm}$ high, are left every few meters to prevent water flow in the zanjas. Excavated material is piled immediately up slope in geometrical bordos $40 \mathrm{~cm}$ high and $80-90 \mathrm{~cm}$ wide at the top, sloping to $130-140 \mathrm{~cm}$ at the bottom. Material in the bordos is not compacted except by incidental foot traffic and thus has larger volume than the zanja from which it came. After zanja-bordo construction is complete, young maguey from nurseries are planted along embankments at $3 \mathrm{~m}$ intervals. Workers are paid by the government on the basis of tareas or jornales, a fair or normal amount of work that can be done in six hours. Tareas are based upon working conditions including types or work, terrain, and material. Table 1 exemplifies the representative tareas for excavation and bordo construction in Tlaxcala.

On the basis of these parameters, it can be estimated that the cost in persondays per hectare of contour terracing on moderate slopes (5 to 10) percent will range from 44 person-days (US \$ 70) on soft soils to 100 person-days (US \$ 160) on hard tepetate. These costs are low indeed when one considers the efficiency of contour terracing in capturing available runoff, enhancing soil mixture for agriculture, and controlling erosion. Tepetate is a hardpan that is exposed to soil surface after erosion has taken place. Contour agriculture lends itself to the use 
of local labor and is suitable for adoption where the mean annual rainfall is 400 $\mathrm{mm}$ or more. In such areas it will definitely help to prevent soil erosion. In the areas where rainfall exceeds $500 \mathrm{~mm}$ a water-catchment terrace technique can be developed to allow for the conservation of excess water. Two important types of storm water catchment technologies are next described: a) silt traps designed to trap both alluvium and runoff; b) check dams designed to impound water for subsequent agricultural or domestic use.

Table 1: $\quad$ Works for zanja-bordo.

\begin{tabular}{|l|c|c|c|}
\hline \multirow{2}{*}{ Material } & \multicolumn{3}{|c|}{ Tareas for zanja-bordo construction } \\
\cline { 2 - 4 } & $\begin{array}{c}\text { Tarea in } \\
\text { linear meters }\end{array}$ & $\begin{array}{c}\text { Approximate cubic meters } \\
\text { (cross section = 0.36m) }\end{array}$ & $\begin{array}{c}\text { Costs pesos per cubic } \\
\text { meter (20 pesos/tarea) }\end{array}$ \\
\hline Soft soil (blando) & $20-25$ & $7-9$ & $2.85-2.25$ \\
\hline $\begin{array}{l}\text { Moderately compacted } \\
\text { (duro) }\end{array}$ & $10-15$ & $21 / 5-51 / 2$ & $5.70-3.65$ \\
\hline Temperate & $5-10$ & $2-31 / 3$ & $10.00-5.70$ \\
\hline Rock (rocoso) & $1-5$ & $1 / 2-2$ & $40.00-10.00$ \\
\hline
\end{tabular}

* 1 peso= $\$$ US 0.80

\subsection{Silt traps}

Silt traps (trincheras and atajadizos) are built of stone across the bed or intermittent streams, often in narrow valleys or gullies. As the alluvium deposits build up, level fields are created behind the check dam walls. As the dam continues to collect alluvium, runoff is stored in the field in the form of soil moisture. An important principle operates in this technique: by capturing runoff from a broad catchment area and concentrating in a reduced area, silt traps transform scarce quantities or rainfall (which otherwise would be lost) into utilizable soil moisture. Larger, more complex silt traps are now in common use in México. These areas are called atajadizo and, like smaller trench, they can be constructed out of rock. However, sometimes other materials such as earth, gravel or logs are used. The runoff and alluvium behind silt traps walls create flood-irrigated agricultural fields. On the basis of extensive interviews with Otomi farmers in Hidalgo, México, Johnson [8], was able to document the principles involved in successful silt trap (atajadizo) construction. Wellconstructed atajadizos incorporate one or more of the following features: double or triple stone walls separated by gravel rubble; walls that extent beneath the surface of stream bed; an outer wall that is pitched up-slope; a floodgate to release excess water; and curved walls allowing storm water to be distributed eventually throughout the field. One important principle of silt trap construction in Hidalgo, concerns the relative heights of the dam wall and the field behind it. Otomi farmers always advise that atajadizo should be kept 0.25 to $0.50 \mathrm{~m}$ higher than the field in order to impound storm runoff successfully and to allow it to infiltrate the soil. Johnson [8], documented structures in one Mexican community ranging from 0.15 to $7 \mathrm{~m}$ in height; 1.5 to $19 \mathrm{~m}$ in length; and 0.1 to $2.5 \mathrm{~m}$ thick. The size of silt trap fields varies from less than two square meters to approximately four hectares. The shape of individual fields depends on gully 
configuration. Like contour terraces, silt traps require investment in human labor rather than capital.

\subsection{Check dams}

Many contemporary check dams probably have been in continuous use since ancient times. In most fundamental ways, the structure and function of modern check dams are the same as their ancient counterparts. Thousands of modern check dam reservoirs serve as catchment seasonal runoff to meet (partially or entirely) the domestic and agricultural needs of peasant communities throughout sub humid México. Frequently, the labor required to construct and maintain these reservoirs is organized under traditional labor-sharing arrangements, thus building up the ancient collectivist heritage of México’s rural communities. These massive structures were built to provide the water supply for haciendas, and thus are different in many ways from the smaller scale community check dams. Hacienda reservoirs owe much to design principles of European origin. Their masonry walls are extremely broad at the base (6-7 m) and are provided with additional supporting buttresses. Lateral spillways are usually provided, and siltation problems are taken care of by sluice gates at the base of the structure.

\subsection{Water catchment in situ}

Anaya et al. [11] developed an equation to calculate the optimum size of microcatchments for agriculture production under rain-fed conditions. The equation is,

$$
\mathrm{D}=\mathrm{D}_{\mathrm{R}}+\frac{(\mathrm{C}-\mathrm{P}) \mathrm{D}_{\mathrm{R}}}{\mathrm{KP}}
$$

$\mathrm{D}=$ micro-basin area (viewed as a unit cross-sectional area) equals the distance between rows, in cm, for crops like corn and soybean; or the width between planting areas (strips), in $\mathrm{m}$, for field crops like barley, grasses, and wheat; or the surface area of tree wells, in $\mathrm{m}^{2}$, for such trees as fruit trees;

$\mathrm{D}_{\mathrm{R}}=$ root area (viewed as a unit cross-sectional area) corresponds to the diameter in $\mathrm{cm}$ of the planting zone for row crops; or the width in $\mathrm{m}$ between strips for fields crops; or to the land area in $\mathrm{m}^{2}$ that tree roots occupy.

Maximum vegetative development for the plants should be considered;

$\mathrm{K}=$ soil runoff coefficient;

$\mathrm{C}=$ consumptive use (in $\mathrm{mm}$ ); and

$\mathrm{P}=$ precipitation based on a $50 \%$ probability during the vegetative cycle $(\mathrm{mm})$.

Another advantage of water catchment systems in situ is related with diminishing effects of drought through periods of 5 to 10 years, which is helpful to ensure basic crops, vegetables, forage and fruits production. The most popular systems of water catchment in México are the following: micro-catchments (micro watersheds), semi-circular bunds, contour bunds for trees, contour ridges for crops, trapezoidal bunds, contour stone bunds, permeable rock dams, and water spreading bunds. 


\section{Description of experiences}

RWHS are intended to collect water from the rain for use in the whole range of human activities, as well as for purified water. Possible uses can be domestic, agricultural, or industrial. RWHS involves collecting, storing and treating rainwater. The construction system of rainwater collection, handling and storage is done with simple technology and locally available materials. Globally water in rivers, lakes, surface reservoirs and aquifers show increasingly impaired, which identifies that rainwater is a meaningful option for the supply. Extensive use of RWHS contributes to sustainable water management, reducing supply problems. Its benefits are environmental and economic, but also reduce shortages and flooding risks; facilitates aquifer recharge, reducing their abatement rates and pollution, restoring its natural conditions. Components of RWHS are the catchment area, conduction system, storage infrastructure, treatment train, and distribution system. For the design, it is considered the demand, the net rainfall, and the catchment area; the train ensure the quality and the storage the continuity of supply for various uses.

The selection and application of technologies on water catchment systems will depend upon the education and motivation of the people, availability of well-trained staff, government policies, and the size of areas to be considered and the level of investment, FAO [12]. RWHS can be used under rain-fed conditions (agriculture, rangeland, and forestry). Depending on rainfall patterns, an optimum use of this natural resource must be achieved; otherwise, uncontrolled run-off may cause erosion and desertification. Also RWHS can be used for human consumption in workplaces, as well as in industrial plants for generation and services.

\subsection{Prototype COLPOS 1}

Is a RWHS that meets the demand of $73 \mathrm{~m}^{3} /$ year family at a budget of $200 \mathrm{l} /$ day, which has cost approximately 3800 USD, satisfying water demand in quantity, quality and continuously. Is it supposed for a net annual rainfall of $1000 \mathrm{~mm}$, and requires a catchment area of $73 \mathrm{~m}^{2}$ of roof-room house. The tank is coated with PVC geomembrane. This system provides potable water for domestic and drinking purified water. This technology option allows water to meet family level and water with treated wastewater vegetables and fruit trees in the backyard, also considers the concept of zero discharge, figure 1.

\subsection{Prototype COLPOS 2}

Is a RWHS for ornamental fish production in ponds and grocery circulars coated with a PVC geomembrane system, conditioned for water circulation and aeration. The cost of this system varies according to its capacity, figure 2 . 

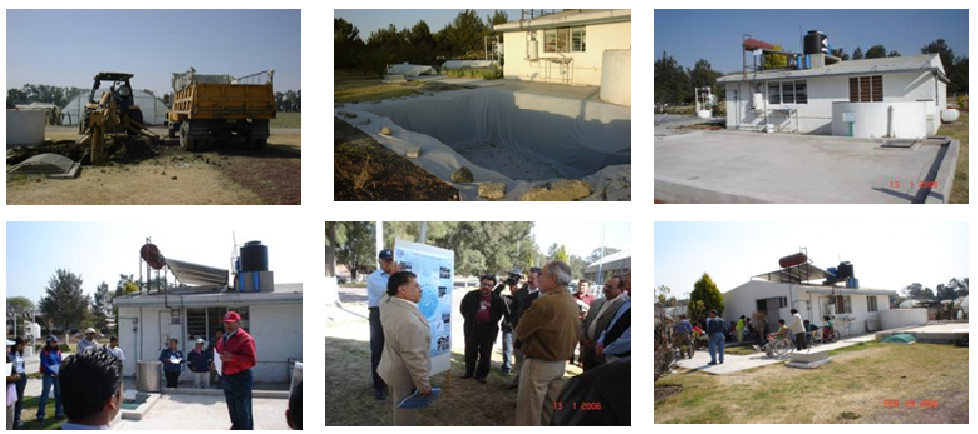

Figure 1: $\quad$ Prototype COLPOS 1.

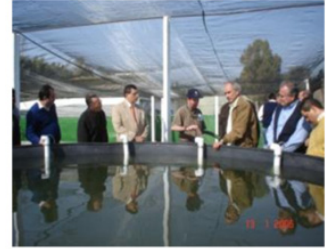

COLPOS 2

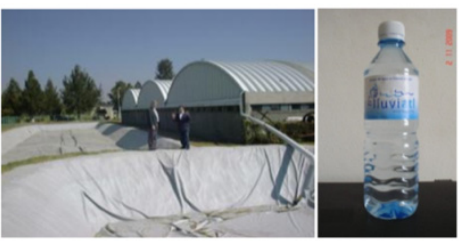

COLPOS 3

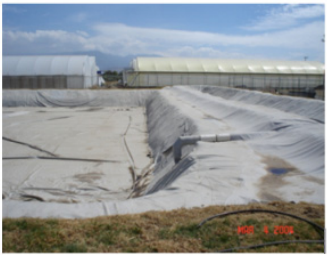

COLPOS 4

Figure 2: COLPOS prototypes.

\subsection{Prototype COLPOS 3}

Is a RWHS designed to meet the demand for drinking water at the community level, to satisfy the demand of purified water for a population of 3000 people, figure 2, under human consumption equivalent to $3 \%$ of body weight. The cost of producing a 19 liter (a carboy water container), is 0.40 USD. The dimensions of the tank are $65 \mathrm{~m}$ long, $15 \mathrm{~m}$ wide and $3 \mathrm{~m}$ deep, lined and covered with PVC geomembrane.

\subsection{Prototype COLPOS 4}

A RWHS to meet demand (consumptive use) of various crops under controlled conditions in greenhouses, capturing rainwater from roofs and stored in a cistern lined and roofed with geomembrane and PVC floats. The RWHS is considered a settler to retain solid particles, figure 2 .

\subsection{Prototype COLPOS 5}

A RWHS to meet the demand of various animal species, water consumption per day is equivalent to $10 \%$ of body weight (a sheep of $50 \mathrm{~kg}$ consumes an average of 5 lt per day). After excavation, the tank is coated and is roofed with PVC geomembrane, with a time life of 10 years, figure 3 . 


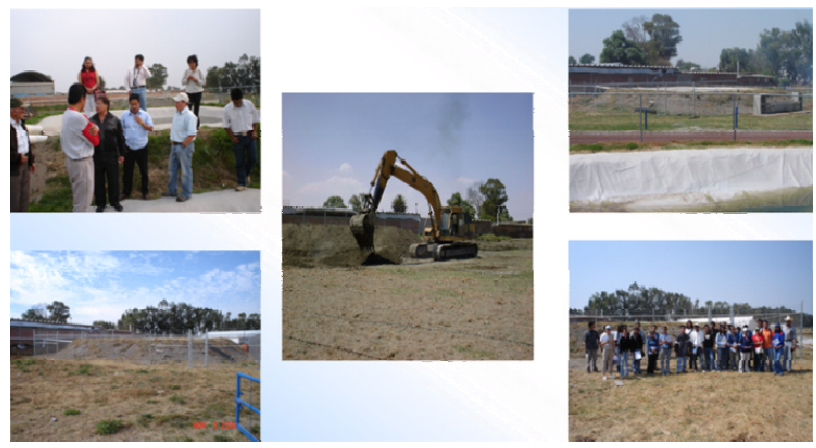

Figure 3: $\quad$ Prototype COLPOS 5.

Table 2: $\quad$ Volume and production for CFE tanks.

\begin{tabular}{|c|c|c|c|c|c|}
\hline Workplace & $\begin{array}{c}\text { Tank } \\
\left(\mathrm{m}^{3}\right)\end{array}$ & $\begin{array}{c}\text { Production } \\
\left(\mathrm{m}^{3} / \mathrm{d}\right)\end{array}$ & $\begin{array}{c}\text { Production } \\
\text { Bottles of 1 } \\
\text { l/year }\end{array}$ & $\begin{array}{c}\text { Production } \\
\text { Bottles of 19 } \\
\text { l/year }\end{array}$ & $\begin{array}{c}\text { Investment } \\
\text { costs (USD) }\end{array}$ \\
\hline AR \& T - 3 & 50 & 0.31 & 75000 & 3409 & 217843 \\
\hline AR \& T - 7 & 225 & 1.38 & 337500 & 15341 & 275953 \\
\hline
\end{tabular}

\subsection{Prototype CFE 1 and CFE 2}

The raison d'être of CFE is the generation, distribution and sale of electricity in México, as well as all works requiring the operation and maintenance of the National Electricity System (SEN). The CFE policies established in the mission, objectives and environmental responsibility demand the sustainable use of natural resources, particularly the water use in all their facilities and workplaces. This is the reason why CFE also has advocated in the application of the RWHS. It was proposed for two sites of CFE two possibilities for tanks of 50 and $225 \mathrm{~m}^{3}$ to solve part of the potable and purified water demands at the workplaces of Augusto Rodín and Tenayuca, located in México City, CFE [13,14], figure 4; table 2 summarizes the results.

Prototypes designed by CIDECALLI and CFE have been patented by the Mexican Institute of Intellectual Property (IMPI), there is also a trademark of purified and bottled water under the brand Lluviatl, figure 2. The previous RWHS already have been replicated within and outside the country, are profitable, competitive and maintained in various marginalized rural populations, which will meet the water demand in quantity and quality for various uses. A logical sequence for the sustainable development is to achieve self-sufficiency in food, water and reach the world in improving the ecological environment. CIDECALLI and CFE normatively promote the use extensive of RWHS in México, and have taken the first steps for the development of the corresponding legislation; in the same way, currently CFE has its own technical guide for the construction of RWHS in all its facilities [15]. 


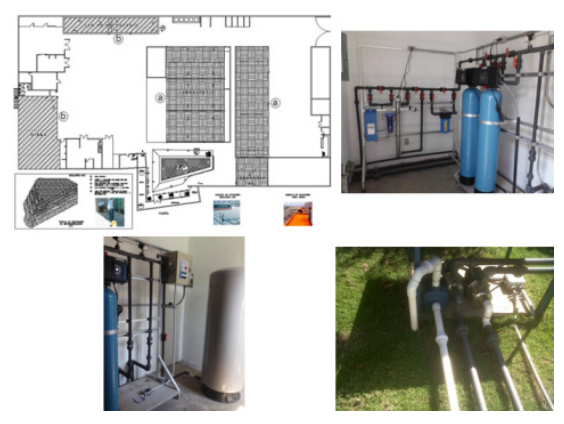

CFE 1
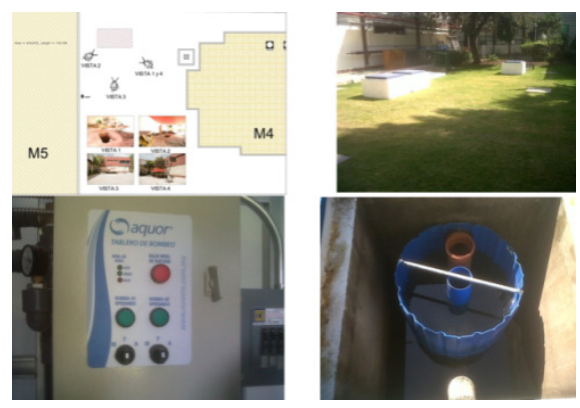

CFE 2

Figure 4: $\quad$ CFE prototypes.

The CIDECALLI has fostered the development and implementation of training projects and supply with rainwater, in sufficient quantity and adequate quality continuously, for human consumption at the household and community levels; the CFE in partnership with CIDECALLI promotes RWHS use in their facilities of generation and services, as well as in their workplaces to provide a sustainable use of water. In the development of RWHS have obtained low construction costs, high profitability and excellent market competitiveness. CIDECALLI have generated technologies on catchment systems for rainwater backyard production in controlled environments for rainfed agriculture for animal consumption, groundwater recharge and control of forest fires. With graduate participants, CIDECALLI and CFE, has formed a network on RWHS in Latin America and the Caribbean, which allows the dynamic exchange of ideas and experiences on the various uses of rainwater. To date 329 people have been trained in the following professions: civil engineers, architects, biologists, physicists, agronomist engineers, foresters, industrial engineers, environmental economists, businessmen, chartered accountants and zootechnical veterinarians, producers and entrepreneurs. It has also established the International Network of Specialized people on Rainwater Harvesting Systems (RIECALLI).

\section{Conclusions}

The RWHS have great social, economic and environmental impact; are highly profitable, competitive and productive projects because they generate jobs and income. Given its low level of technological complexity, are extrapolated and easily adaptable to various cultural, social, economic and ecological scenarios. It is possible to set up programs in Regional, National, State, Municipal, and Community levels and strengthen training programs for the design, construction and maintenance of the various RWHS. The CIDECALLI promotes and teaches the use of RWHS and developed with different partners such as the CFE the RIECALLI, meanwhile the CFE requires sustainably use of water in their generating facilities and services including their workplaces, being with this a direct application of RWHS in industry. It is possible to supply drinking water 
for communities with government support, through subsidies for the construction of various types of cisterns. The access to clean and safe water is a universal right established by the United Nations Organization.

\section{References}

[1] Anaya-Garduño, M., Manual del participante: XVIII Diplomado internacional sistemas de captación y aprovechamiento del agua de lluvia, COLPOS, 550 pp., 2012.

[2] Anaya-Garduño, M., Captación del agua de lluvia: solución caída del cielo, Mundi-Prensa, México, D.F., 132 pp., 2011.

[3] E-Source, WASH News and Features: http://www.source.irc.nl/page /26980.

[4] HarvestH2O.com: http://www.harvesth20.com/cidecalli_study.shtml.

[5] UNEP, Source book of alternative technologies for freshwater augmentation in Latin America and the Caribbean, Washington, D.C., pp. 33-98, 1997.

[6] Patrick, L. A., Cultural geography of the use of seasonally dry sloping terrain: The Metlepantli crop terraces of Central Mexico, University of Pittsburgh, Ph.D. Dissertation, 1977.

[7] Anaya-Garduño, M., Technology and desertification. In: Desertification: its causes and consequences, Pergamon Press, Oxford, England, pp. 319-448, 1977.

[8] Johnson, K., Do as the land bids. A study of Otomi resource-use on the eve of irrigation, Clark University, Ph.D. Dissertation, 1977.

[9] Sanders, W. and Carlton, T., The Teotihuacan Valley project final report. Vol. I. The natural environment, contemporary occupation, and $16^{\text {th }}$ century population of the valley. Pennsylvania State University, Occasional Papers in Anthropology, 1970.

[10] Wilken, G., Studies of resource management in traditional middle American farming systems. No 5: Surface geometry, part one: Slope Management, Colorado University, 176 pp., 1976.

[11] Anaya-Garduño, M., Sistemas de captación de agua de lluvia en América Latina y el Caribe: Base para el desarrollo sostenible, Manual Técnico, IICA, México, D.F., 96 pp., 1998.

[12] FAO, Water catchment. A manual for the design and construction of water catchment schemes for plant production, Rome, Italy. 133 pp., 1991.

[13] Martínez-Nájera, J.D., Moreno-Valle-González, L.I., Aragón-Escamilla, P.E., Figueredo-Rodríguez, H., Villalobos-Martínez, A., Martínez-Castillo, B.E. and Franco-Hernández, L.E., Proyecto ejecutivo para el sistema de captación, potabilización y purificación del agua de lluvia en la GEIC de CFE, CT Augusto Rodin, Reporte CFE, Dirección de Proyectos de Inversión Financiada/GEIC/ SEH, México, 185 pp., 2010.

[14] Martínez-Nájera, J.D., Carmona-Ricárdez, E., Moreno-Valle-González, L.I., Figueredo-Rodríguez, H. and Martínez-Castillo, B.E., Proyecto ejecutivo para el sistema de captación del agua de lluvia en la GEIC de 
CFE, CT Tenayuca, Reporte CFE, Dirección de Proyectos de Inversión Financiada/GEIC/SEH, México, 151 pp., 2011.

[15] Martínez-Nájera, J.D., Carmona-Ricárdez, E., Alonso-Gutiérrez, G. and Martínez-Castillo, B.E., Elementos y lineamientos para sistemas de captación de agua de lluvia, Guía CFE 01G00-53, LAPEM Normalización y Metrología, México, 15 pp., 2012. 